\title{
The alpine rural landscape as a cultural reserve: the case study of Teglio in Valtellina
}

\author{
Giorgia de Pasquale ${ }^{1} \cdot$ Eugenia Spinelli $^{1}$
}

Received: 28 May 2021 / Revised: 15 September 2021 / Accepted: 16 September 2021 /

Published online: 6 October 2021

(C) The Author(s) 2021

\begin{abstract}
This research examines a portion of the Italian alpine landscape in order to find a comprehension mode and a strategic proposal to safeguard this rural heritage. The area is located in Valtellina, in the municipality of Teglio (Sondrio, Italy), between 700 and $1200 \mathrm{~m}$ a.s.l. Typical characteristic of the local landscape conformation is fragmentation, which determines a rapidly changing chequerboard depending on the rotation of seasons and cultivation. The landscape alternates wooded and cultivated areas. Cultivations mainly concern rye, buckwheat, corn, barley, alpine wheat, chestnuts and small orchards and have a wide agrobiodiversity and especially a historical and cultural value. The cultivation of buckwheat, for example nustran arrived in the valley in the XVII century and Teglio is the place where it persists more. The genotypes present are in part already classified, in part under study. The vernine crop alternated to buckwheat is mainly rye, arrived in the valley since the XV century. The local varieties formed over time are a resource of genotypes adapted to high altitude agricultural environments, they have important nutraceutical properties and they are closely associated with the local culture. The aim was to verify the persistence of traditional crops in the area, together with the cultural value of the traditional rural system, in order to analyse the feasibility of a strategy for the preservation of biocultural diversity. The research has shown how, despite the dynamics of depopulation and abandonment of agricultural fields, there is still in the area a sufficient permanence of cultural practices and social uses that can be a solid starting point for a sustainable development of the territory that focuses on agricultural and cultural biodiversity.
\end{abstract}

Keywords Historical rural landscapes · Cultural landscapes $\cdot$ Cultural heritage $\cdot$ Alpine landscapes

Communicated by Mauro Agnoletti.

Eugenia Spinelli

eug.spinelli@gmail.com

Giorgia de Pasquale

giorgia.depasquale@uniroma3.it

1 Present Address: Department of Architecture, University Roma Tre, Via Aldo Manuzio 68L, 00153 Rome, Italy 


\section{Introduction}

In Italy humans have largely shaped the territory to make it fertile and cultivable and have selected some cultural species, thus creating a cultural biodiversity, specific to this area of the Mediterranean (Braudel 2003; Barbera 2019, 2021). Today, traditional agriculture is still practiced in small sections of land, with an important decrease of cultural and environmental value (Agnoletti 2013, 2014; Agnoletti and Rotherham 2015). Moreover, during the last decades, particularly from the $50 \mathrm{~s}$ to the present, a strong gap has arisen between urban poles and peripheral areas. Hence, small municipalities have been emptied of services and people (Barca et al. 2014). In Italy this issue has been addressed by the National Strategy of Inner Areas, SNAI, which classifies the territory according to a criterion of distance, in terms of time, from essential services. It proposes the development of ad hoc strategies for the improvement of services and the mending of distances from the rest of the country (Barca et al. 2014).

The research focuses on the rural landscape of the Italian Alps, one of the most anthropized mountain ranges on Earth, presenting a wide biodiversity and strong cultural ethnodiversity (Salsa 2019). The aim is to study the presence of portions of the territory of the Municipality of Teglio in Valtellina, that can be classified among the historical rural landscapes, built over the millennia that, while continuing in their evolutionary process, retain clear evidence of their historical origin, maintaining an active role in society and economy (Agnoletti 2010). These landscapes are also often characterized by a strong biodiversity and by the use of traditional techniques that do not require large external input (Emanueli 2016). In Italy, in order to protect these sites, the National Register of Historic Rural Landscapes has been established in 2012 by the Ministry for Agricultural Food and Forestry Policies, MIPAAF. As with the UNESCO World Heritage List and the FAO's Globally Important Agricultural Heritage Systems (GIAHS) programme, it is aimed at protecting the landscape cultural heritage. Furthermore, it is characterized by the focus on the agricultural, forestry and pastoral activities that have shaped the territory throughout history.

Following the guidelines of the National Observatory of Rural Landscapes, geomorphological, socioeconomic and historical characteristics of the site area were analysed. The study takes into consideration the dynamics that have occurred in the territory from the Second World War to the present day, particularly with regard to land use, to verify the historicity of the rural landscape. Once the permanence of land uses was confirmed, the research focused on understanding the permanence of local cultural values. Hence, the investigation focused on the ways of living that characterize the place and the cultural elements that have shaped the landscape. Therefore, the community of local heritage (Coe 2005) was included, as keeper of local knowledge and witness of the added value of living a cultural landscape where it is possible to identify with (Salsa 2019).

In this article we refer to Landscape as in the European Landscape Convention, namely as an area, as perceived by people, whose character is the result of the action and interaction of natural and/or human factors (Coe 2000).

We refer to the rural landscape as defined by Emilio Sereni, that shape that the man, in the course and to the ends of its agricultural productive activities, impresses to the natural landscape (Sereni 1961). The analysis is implemented with special attention to those signs which refer to cultural, economic, political and social relationships (Turri 1974). In fact, the rural landscape is the result of the interpenetration of culture and nature, it is a testimony of our history and changes with the evolution of society. These landscapes can 
be considered cultural landscapes, as they are fashioned from a natural landscape by a cultural group. Culture is the agent, the natural area the medium, the cultural landscape the result (Sauer 1925).

\section{Materials and methods}

\section{Site area}

Teglio is a small Lombardy municipality, situated in Valtellina, Italy (Fig. 1). It extends along $115 \mathrm{~km}^{2}$ with variable altitudes from 300 to $2400 \mathrm{~m}$ above sea level. According to the classification adopted within the SNAI, the Municipality falls within the inner areas at an intermediate level hence at a distance from essential services of between twenty and forty minutes (Barca et al. 2014).

The area under examination covers 1564 ha within the municipality of Teglio, occupying about $14 \%$ of the municipal territory. The area is divided into two non-contiguous parts (Fig. 2), one on the Rhaetian side of 958.6 ha, the other on the Orobic side of 605.5 ha. The minimum distance between the parts is equal to $1,93 \mathrm{~km}$. The territory of the municipality is for the $92 \%$ mountainous (Merizzi and Cicardi 2012) and is cut longitudinally by the Adda River (Fig. 3), which divides the Rhaetian Alps from the Orobian Pre-Alps (Gianasso

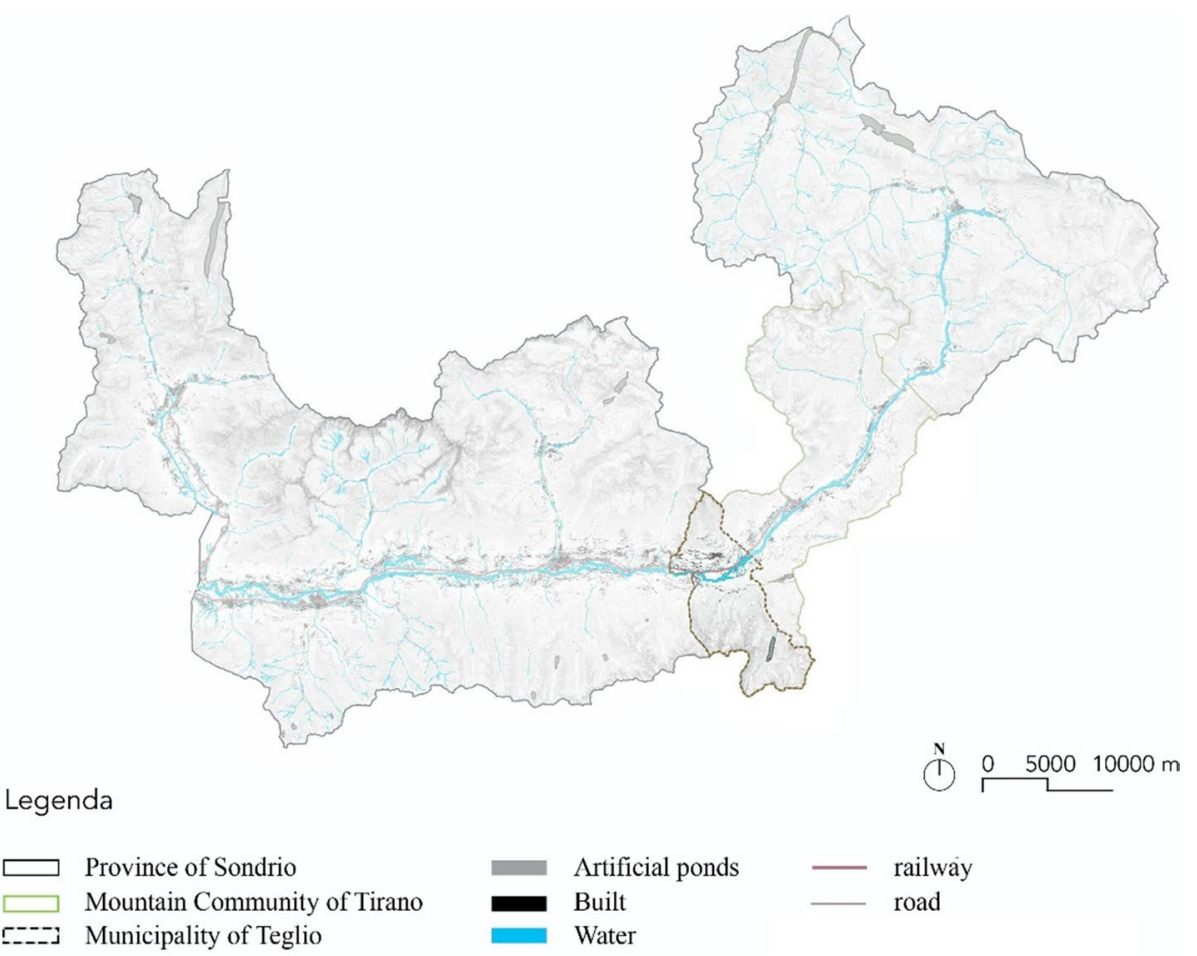

Fig. 1 Overview of the Province of Sondrio and location of the Municipality of Teglio $\left(46^{\circ} 102032 \mathrm{~N}\right.$ $10^{\circ} 04^{\prime} \mathrm{E}$ ) 


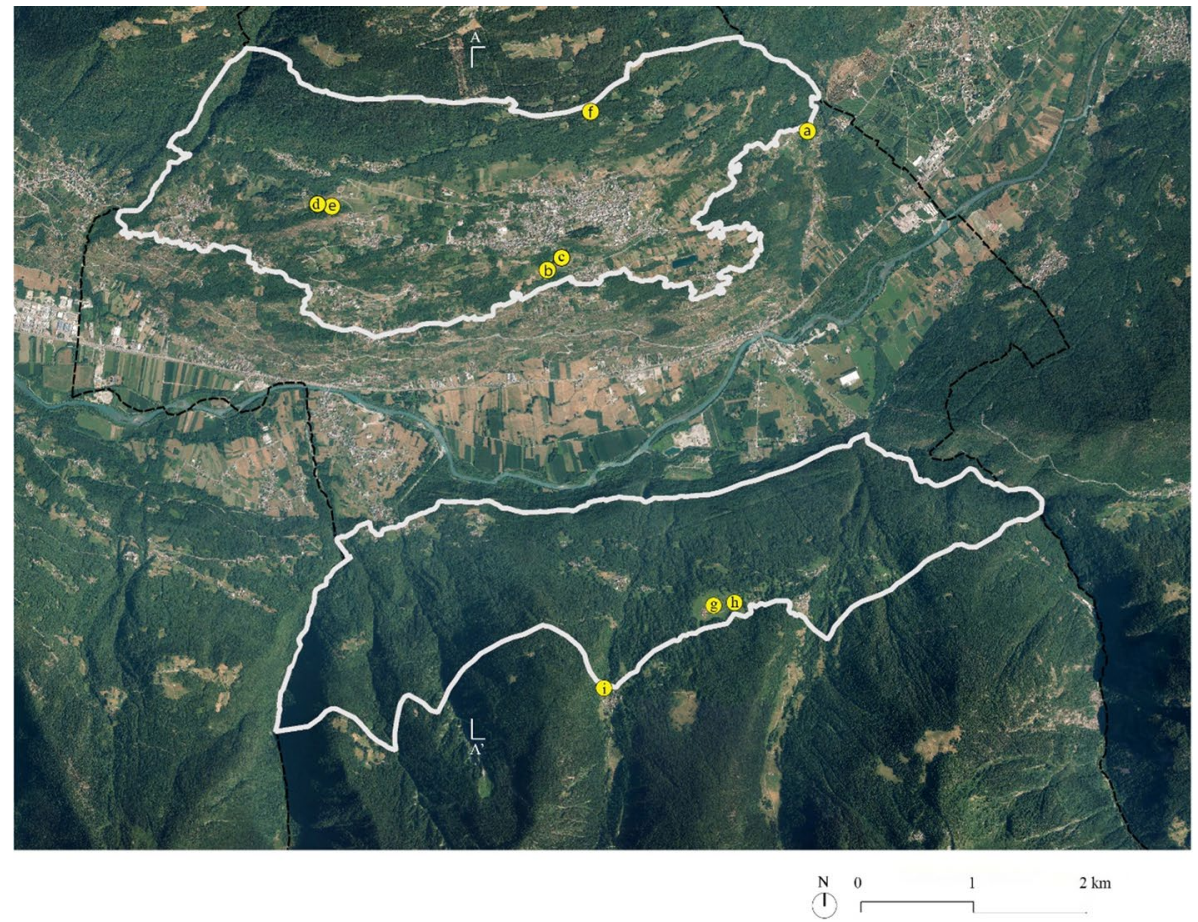

Case study areas
Localization photographs fig. 3

Fig. 2 Site area

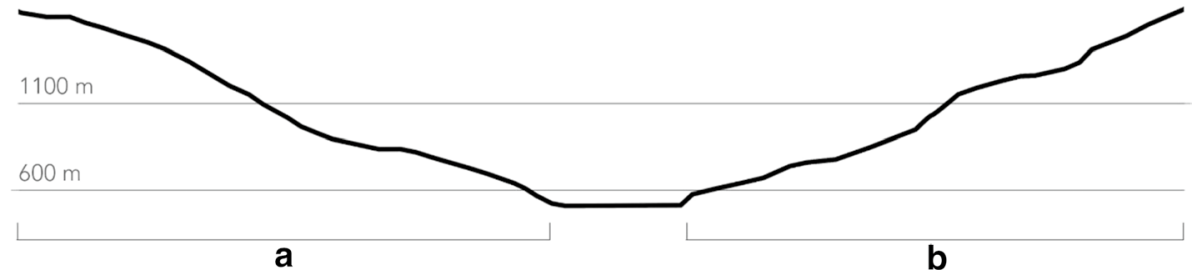

Fig. 3 Section AA' marked in Fig. 2. a: Rhaetian slope; b: Orobic slope

1971). The area has wooded areas and cultivated areas on terraces, those dedicated to vineyards have a maximum depth of $15 \mathrm{~m}$, those dedicated to arable crops and meadows are deep up to $40 \mathrm{~m}$ and located at higher altitudes. They are made up of fertile topsoil, transported from the valley to the mountain. To support the terraces, there are gray-green dry-stone walls, built in serpentine, with the stones available on the slopes. On the geomorphological aspect, the municipality of Teglio is part of the Southalpine and Austroalpine orogen, whose division is related to the presence of the Tonale fault (Gianasso 1971). In the Province of Sondrio there are gneisses, micascists, ancient granitoid rocks, minute gneisses, marble limestones of the archaic Paleozoic era; clay and arenaceous schists of the 
orobic chain, and conglomerates of the orobic chain dating back to the Permian; limestones and serpentines of the Mesozoic era; granitoid rocks of the Màsino of the Cenozoic era (Giacomini and Nangeroni 1960).

The history of Teglio is strongly linked to agriculture as evidenced by the stela of Caven, rock engravings dating back to the third millennium BC. Found between 1930 and 1968 in the territory of Teglio among the terraced vineyards of the Rhaetian side, they are proof of the existence of an agricultural civilization already developed in the Copper Age (Benedetti and Benedetti 1984). From the tenth century onwards, Benedictine monks began the work of reclamation by eliminating the woods in order to create fields, among which vines were the most important cultivation (Zoia 2004). In the 1600's the cultivation of buckwheat, rye and chestnuts became widespread (Guler Von Weineck 1959). Corn and potatoes were added in the 18th century. The Statute in force from the 15 th to the 18 th century reports the rules for the use of the land and agricultural practices. Specifically, it deals with the division between collective, community and private properties and the distinction between tense and free woods. Therefore, it refers to grazing, cattle and swine breeding, cereal cultivation and the management of woods and chestnut forests (Zoia 1996).

Teglio is a medieval village that stands on a plateau located on the Rhaetian slope at an altitude of $800 \mathrm{~m}$ a.s.l. (Palladini 2012). The rural built landscape presents the following main elements: terraces with dry stone walls, mills, sites for the conservation of chestnuts (matati), isolated rustic houses, aggregated rustic houses. The materials used are wood, mortar and stone, founded in the proximity of the construction. The wood is chosen according to the use with a prevalence of chestnut, then larch, pine, poplar and fir. The houses are single-family or multi-family with a structure in stone and wood, used for the internal structure and the external balcony that extends the volume of the highest levels. The roof is pitched or rarely single pitch and still has the roofing in piode, serpentinite slabs. House, storage and stall for animals coexisted under the same roof (Bonardi et al. 2014).

On the lower slopes of the Rhaetian, where the land has not been devoted to agriculture, there are forests of Oak (Quercus pubescens, Q. sessiliflora), Hornbeam (Ostrya carpinifolia) and Manna Ash (Fraxinus ornus) (Fig. 4). In the area between 300 and $700 \mathrm{~m}$ a.s.l. the main cultivation is the vine (Fig. 5a), which between 700 and $800 \mathrm{~m}$ a.s.l. coexists with arable land. Among the cultivations of the vineyards, there are small meadows of glaucous grasses as Festuca, Carthusian carnations, Liliaceae and Umbelliferae.

Pollarded willows (Salix viminalis, Salix caprea) are distributed among crops and provide long, thin branches, called salecs, that are used to tie up vines (Cicardi 2005). Above $800 \mathrm{~m}$ a.s.l. are the fields of arable land and meadows (Fig. 5c, d, h) alternating with chestnut woods, (Castanea sativa) (Fig. 5b), while vegetable gardens and orchards are located in small plots on the edge of the villages, on the plateaus between 800 and $900 \mathrm{~m}$ a.s.1. Chestnut groves are kept in coppice and today the only treatments consist in rare cleanings of the foliage to be used as beds for husbandry and harvest. As for the varieties present, the municipality of Castello dell'Acqua, bordering with that of Teglio, has documented the presence of: Fugascèra; Savòn; Rossera; wild species, including Catot, Pelosa, Tardiva, Pezzadina (Buzzetti 2005). The forest used for timber is mainly composed of Larix decidua, Betula, Picea abies, Populus alba, Prunus avium (Fig. 5f, g, i).

Buckwheat is present in many ecotypes which are still being identified by means of genetic research. Buckwheat, Fagopyrum esculentum, called formentone or fraina, belongs to the family of Polygonaceae (Value Sustainable Agri-Food and Environment 2018). It is an annual herbaceous plant with a short vegetative cycle, it is used as an autumn summer intercrop, in succession to winter cereals such as wheat, rye or barley. To the same genus of buckwheat belongs also Siberian wheat, Fagopyrum tartaricum, called zibèria or 


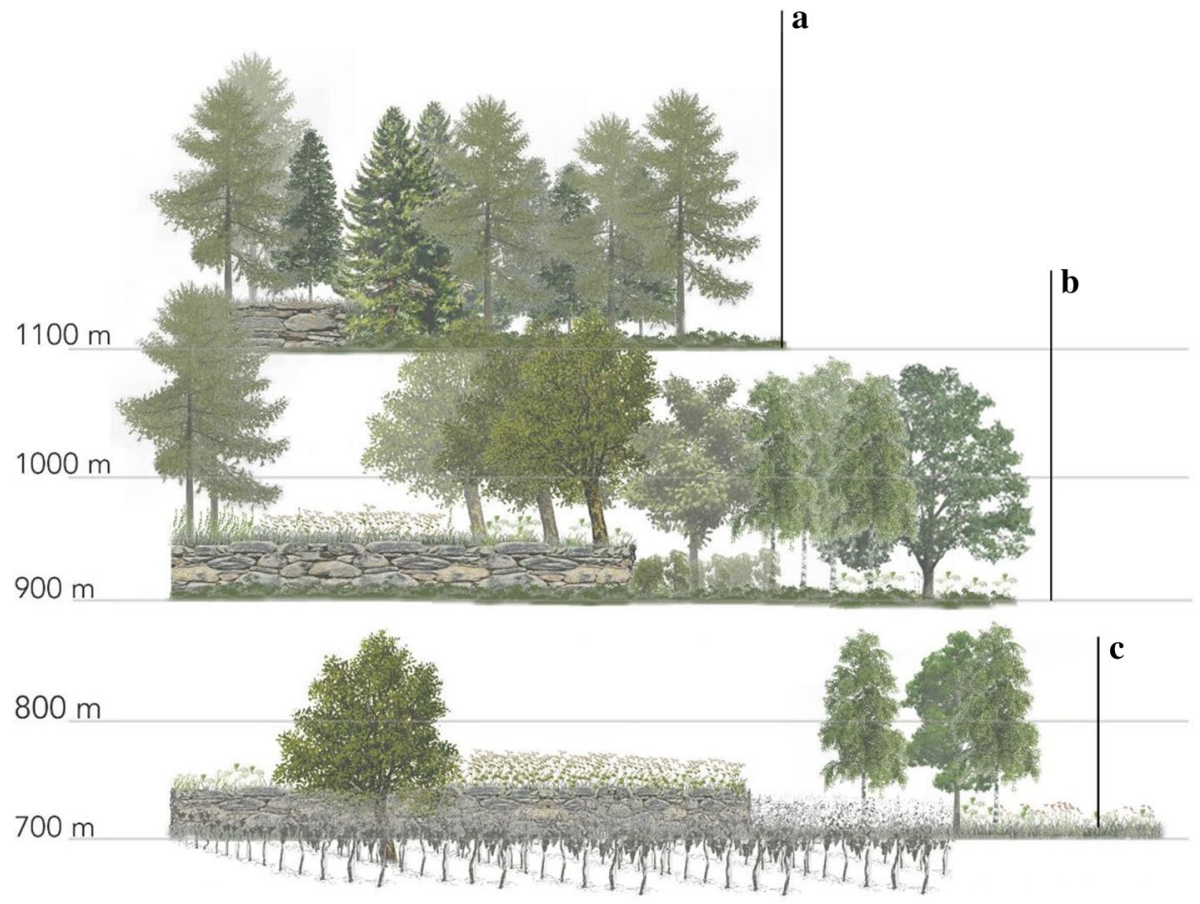

$600 \mathrm{~m}$

Fig. 4 Study area zoom, Rhaetian slope vegetation section diagram. a (1100-1300 m a.s.1.): Cedrus, Larix Decidua, Picea abies, Abies Alba; b (900-1100 m a.s.1.): Betula, Castanea Sativa, Dianthus Carthusia, Fagopyrum Esculentum, Fagopyrum Tataricum, Fraxinus Excelsior, Larix Decidua, Liliaceae, Quercus Pubescens, Umbelliferae; c (700-900 m a.s.1.): Betula, Castanea Sativa, Dianthus Carthusia, Fagopyrum Esculentum, Fagopyrum Tataricum, Fraxinus Excelsior, Liliaceae, Quercus Pubescens, Umbelliferae, Vitis vinifera

anzibaria. Rye, Secale cereale, called séghel or blá (Berti and Branchi 2002) is a gramineous cereal and it is the most used winter cereal in alternation with buckwheat. The latter resists to higher altitudes, even in situations of frost and has important nutraceutical properties that favour its use for functional foods. Above the chestnut tree or in the highest higher areas where the latter still develops, then up to $800 \mathrm{~m}$ above sea level, we find a mixed forest of Hazel, Corylus avellana, and Lime, Tilia, with the presence of Oaks, Quercus, and Poplar, Populus tremula. Beyond $900 \mathrm{~m}$ a.s.l. we find transitional belts formed by Birches, Betula and Larchs, Larix decidua, beyond $1100 \mathrm{~m}$ a.s.l. we find the Abies, Abies alba, and the Spruce, Picea abies, higher up the forest of Scots Pine, Pinus sylvestris, leave space for the prairies and the mountain pastures beyond $2000 \mathrm{~m}$ a.s.l. This zone has also undergone some modifications due to human activities, as birches have been preferred to firs, since they allow for a brighter undergrowth and are therefore mainly herbaceous, suitable for grazing, and proliferates, favouring the possibility of using the wood for firewood.

In the Orobian Alps, on the other side of the valley, at $400 \mathrm{~m}$ a.s.1., there are chestnut woods, often still cultivated, and Oak forests, Quercus robur, with the presence of Elms, Ulmus, and deciduous woods. The prevailing cultivations are arable land and permanent meadows (Fig. 5h). 

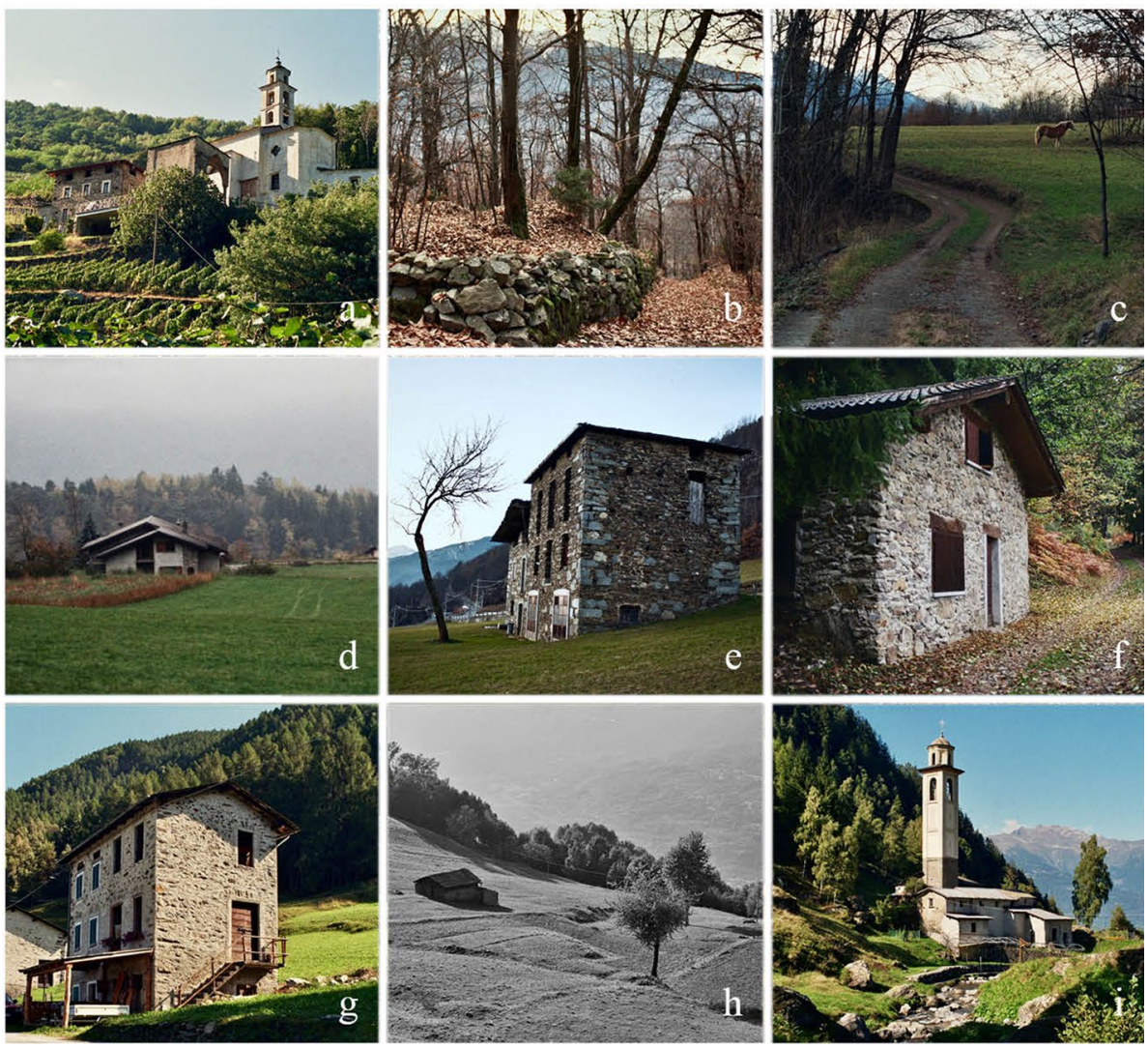

Fig. 5 a Terraced vineyards and $S$. Abbondio church, $\left(46^{\circ} 10^{\prime} 43.151^{\prime \prime} \mathrm{N}, 10^{\circ} 5^{\prime} 37.726^{\prime \prime} \mathrm{E}\right)$, August 2019; b: chestnut wood $\left(46^{\circ} 10^{\prime} 3.959^{\prime \prime} \mathrm{N}, 10^{\circ} 3^{\prime} 21.165^{\prime \prime} \mathrm{E}\right)$, December 2019; c: arable fields and meadows $\left(46^{\circ}\right.$ $\left.10^{\prime} 8.187^{\prime \prime} \mathrm{N}, 10^{\circ} 3^{\prime} 48.263^{\prime \prime} \mathrm{E}\right)$, December 2019; $\mathbf{d}$ arable fields and meadows (46 $10^{\circ} 24.838^{\prime \prime} \mathrm{N}, 10^{\circ} 2^{\prime}$ 29.524" E), December 2019; e arable fields and meadows ( $\left.46^{\circ} 10^{\prime} 28.347^{\prime \prime} \mathrm{N}, 10^{\circ} 2^{\prime} 34.023^{\prime \prime} \mathrm{E}\right)$, December 2019; f: mixed woods and meadows (46 $\left.10^{\prime} 28.515^{\prime \prime} \mathrm{N}, 10^{\circ} 2^{\prime} 34.107^{\prime \prime} \mathrm{E}\right)$, December 2019; $\mathrm{g}$ rural house, $\left(46^{\circ} 8^{\prime} 25.305^{\prime \prime} \mathrm{N} 10^{\circ} 4^{\prime} 50.840^{\prime \prime} \mathrm{E}\right)$, September 2019; $\mathbf{h}$ arable fields and meadows Orobian Alps, $\left(46^{\circ} 8^{\prime}\right.$ 26.833" N 10 4' 56.560" E)September 2019; i: San Lorenzo, Bondone, Orobian Alps, (46 7' 59.875" N $10^{\circ} 4^{\prime} 2.771^{\prime \prime}$ E), September 2019. Photographic project by Giovanni Conte

Teglio invests two of the five oro-geographic districts in which the Province of Sondrio has been divided. The Rhaetian side is part of the Central Rhaetian sector with the presence of crystalline silicate lithotypes, while the Orobic side is part of the Orobian Alps sector, where the climate is more oceanic (Ferranti et al. 2005, Ferranti 2011, Gironi et al. 2012). Below is a list of some of the species present, composed by referring to the database of the Observatory for Biodiversity of the Lombardy Region in the locality of Teglio and to the manual for the monitoring of species and habitats of community interest developed by the Superior Institute for Environmental Protection and Research (ISPRA): Cladonia, Buxbaumia viridis, Leucobryum glaucum, Aquilegia alpina, Arnica montana, Artemisia genipi, Cypripedium calceolus, Gentiana lutea, Gladiolus palustris, Lycopodium, Primula glaucescens, Saxifraga presolanensis (Bacchetta et al. 2016), Asplenium trichomanes, Carex digitata, Pinus sylvestris, Orthilia secunda, Picea abies, Oxalis acetosella, Festuca heterophylla, Galeopsis pubescens, Corylus avellana, 
Dactylorhiza maculata, Chaerophyllum hirsutum, Clematis alpina, Luzula nivea, Lonicera xylosteum, Maianthemum bifolium, Melica nutans, Hepatica nobilis, Hieracium mororum, Gymnocarpium dryopteris, Saxifraga cuneifolia, Vaccinium myrtillus, Valeriana montana, Sorbus aucuparia, Solidago virgaurea, Veronica urticifolia, Viburnum lantana, Viola riviniana, Polypodium vulgare (Osservatorio Regionale per la Biodiversità Lombardia 2021). To these are added the species detected in situ, shown in Figs. 4 and 6.

According to the classification of Rivas-Martinez, the Province of Sondrio is divided into two bioclimatic strata: the oceanic temperate belt that falls in most of the provincial territory, mainly in the North, the continental temperate belt in the South (RivasMartìnez et al. 2004). Regarding the thermoclimatic classification, Valtellina presents a supratemperate climate with zones with orotemperate climate (Rivas-Martìnez et al. 2004). The Umbrothermal diagram (Fig. 7) of the meteorological station of Sondrio shows a continental rainfall regime, with no arid periods, following the climatic index of Bagnoulus and Gaussen (the condition " $\mathrm{P}<2 \mathrm{~T}$ " is never recorded) (Rappelli et al. 2007).

**This article reports a summary of Eugenia Spinelli's dissertation discussed in 2019 in the Department of Architecture, University of Roma Tre (supervisor: Giorgia De Pasquale) with the collaboration between Giancarla Maestroni, Department of Education Sciences, Catholic University of Milan and exponent of the Association for the cultivation of buckwheat of Teglio and traditional alpine cereals, the Department of

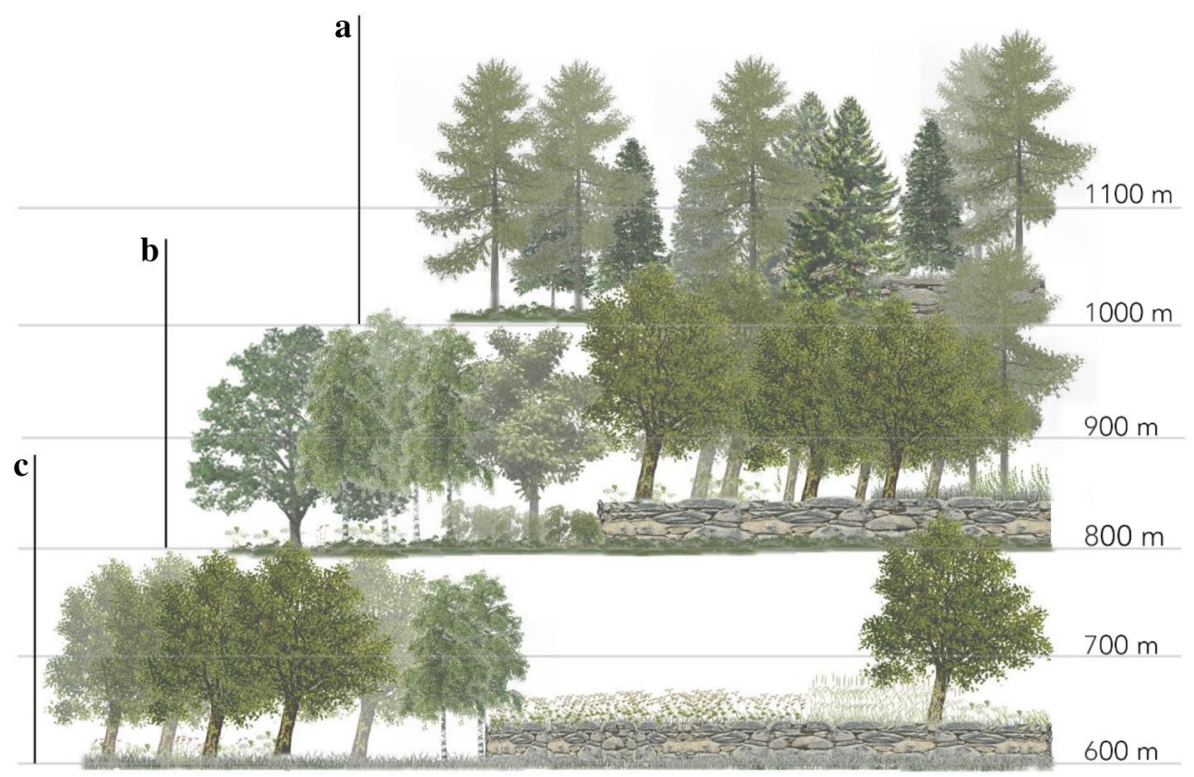

Fig. 6 Study area zoom, Orobic slope vegetation section diagram. a (1000-1100 m a.s.1.): Cedrus, Larix Decidua, Picea Abies, Abies Alba; b (800-1000 m a.s.1.): Betula, Castanea Sativa, Dianthus Carthusia, Fagopyrum Esculentum, Fagopyrum Tataricum, Fraxinus Excelsior, Larix Decidua, Liliaceae, Quercus Pubescens, Umbelliferae; c (600-800 m a.s.1.): Betula, Castanea Sativa, Dianthus Carthusia, Fagopyrum Esculentum, Fagopyrum Tataricum, Fraxinus Excelsior, Liliaceae, Quercus Pubescens, Umbelliferae 
Fig. 7 Umbrothermal diagram of the Sondrio metereol station 2001-2007 (Rappelli et al. 2007)
Sondrio

(307 m; 11,4 ${ }^{\circ} \mathrm{C} ; 836 \mathrm{~mm}$ )

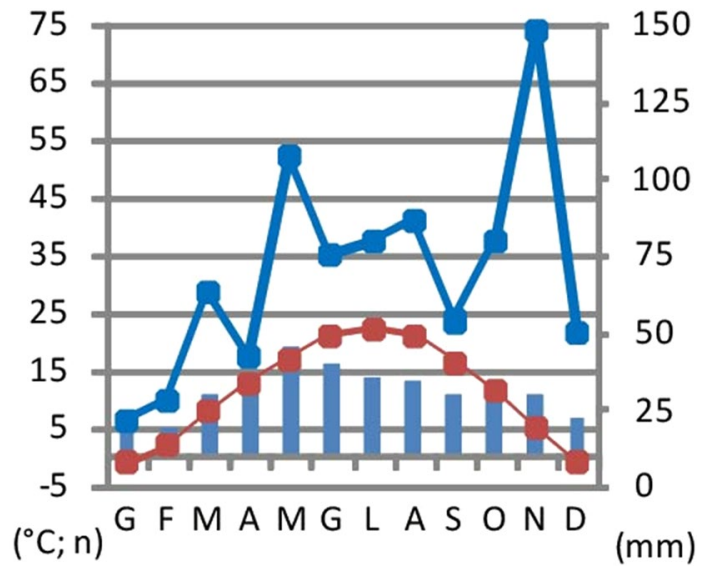

Agricultural, Food, Environmental and Forestry Sciences and Technologies (DAGRI) of the University of Florence and the Department of Architecture of the Roma Tre University.

\section{The methodology}

The study aims to explore the multidimensional biodiversity of the study area, including both the ecosystem and cultural dimensions. For this purpose, a cross-disciplinary analysis was divided into three areas: historical-environmental, socio-economic, historical and socio-cultural.

\section{Historical-environmental analysis}

We used the VASA methodology, Historical and Cultural Evaluation Approach (Agnoletti 2007), to understand the evolution of the landscape from the second post-war period to the present day. The VASA analysis is the official methodology used by the Ministry for Agricultural Food and Forestry Policies, Mipaaf, for the approval of applications for the National Register of Rural Historic Landscapes. The evaluation of anthropogenic influence, land transformations and cultivation practices was done through photointerpretation: two aerial photos are analyzed and compared. In the case under analysis, the first photo is from 1954, the second from 2015. Once the uses of land of both past and present are obtained, we proceed comparing the data collected to better understand the evolutionary dynamics of the area under consideration. (Agnoletti and Tempesta 2016). The land use (LU) of the two reference periods was extrapolated through photointerpretation of the GAI, Gruppo Aereo Italiano 1954 aerial flight for the post-World War II period and of the AGEA, Agenzia per le Erogazioni in Agricoltura 2015 orthophoto for the current state, already georeferenced. The GAI 1954 aerial flight is provided in black and white at a scale of 1: 45,000, has a 
resolution of 2500 DPI. The 2015 orthophoto has a scale of 1:5000 and a definition of $20 \mathrm{~cm}$ pixels. The digitization of the information and subsequent analysis were processed in the open source GIS environment QGis ${ }^{\circledR}$. The data were geolocated through the UTM fused $32 \mathrm{~N}$ reference system with WGS84 datum, identified by EPSG code 32,632. The georeferencing of the GAI Flight was done in the QGis environment, using the Georeferencer Plugin. The georeferencing was done without known parameters, using the current cartography as the reference dataset, finding a minimum of four corresponding GCP points and applying the polynomial transformation method. The maximum number of GCP points used is 50 , the median is 15 . Maximum error is $15 \mathrm{~m}$, median is $7 \mathrm{~m}$.

The land use map has a minimum mappable unit of $250 \mathrm{~m}^{2}$. We identified six land uses: arable land and meadows, vegetable gardens and orchards, vineyards, urban and anthropized areas, forests, shrub and arboreal vegetation. The choice not to distinguish specific arable land and the latter from grassland is due to the practice of crop rotation carried out independently by the inhabitants over a variable period of time, the presence of fallow land, and the difficulty of photointerpretation. The low quality of the 1954 aerial photo also made it impossible to analyse the parcelling and evolution of linear elements such as dry stone walls, rows of trees, etc. Photointerpretation, was done de visu, recognizing land uses and creating two different shape files, one for each time period. Overlaying the 1954 and 2015 land use mappings, using the intersect tool of geoprocessing, allowed the creation of a new cartography that shows the dynamics of land transformation, separating the areas that have remained unchanged from those that have undergone a change of use (Agnoletti 2007; Agnoletti and Tempesta 2016). The VASA methodology distinguishes seven dynamics: stable, intensification, extensification, forestation, deforestation, coniferation and urbanization (Agnoletti 2006a, b). Thus, the use of this analysis is aimed at quantifying the extent of cropland abandonment and the dynamics that have affected land uses over more than half a century.

\section{Socio-economic analysis}

The goal was to define the main risk factors, studying demographic trends, the rate of employment in the agricultural sector, the structure and organization of companies, crop production and the impact of tourism. The description of the structure, senilization, old age index and general dynamics of the resident population in the City of Teglio was analyzed on the basis of National Institute of Statistics, ISTAT, data (Istat 2011). While the information regarding the structure and organization of farms was derived from ISTAT data from the 6th Census of Agriculture (started in 2010, published in 2014). With regard to the evolution of tourism in the territory, the data reported has been extrapolated from the statistical dossier produced as part of the 2016 program of activities of the Regional Observatory of Tourism and Attractiveness. In addition, we analysed the planning system, the active urban planning tools, the participating entities and the main sponsors. Instruments and actors are divided into thematic groups according to the directions of which they are promoters.

\section{Historical analysis}

The goal was to discover the local material and immaterial heritage, investigating the site's rural history, traditional architecture, vegetation and visual value of landscape.

The research methods were bibliographic, archival and on-site survey. In particular, the documents that allowed us to trace the evolution of local agriculture were the Statutes, in 
force between the 15th and 18th centuries, the land registers, the surveys, the rents and the taxes (Zoia 1996). We proceeded with a historical analysis that allowed us to reconstruct the origins of the local landscape, to draw timelines able to synthesize the events and to identify the agricultural practices still in use and those that have fallen into decline.

Once the historical investigation was completed, we continued with the research of the signs left in the landscape by the community and its evolution, the built landscape. We identified the architectural typologies and we studied the construction techniques of the historical artifacts, in particular of the mixed structures in dry stone and wooden beams. Moreover, we investigated the settlement structure and its variations between villages of different size and position on the slopes.

The vegetation landscape was investigated in its individual parts, combining historical, ecological and compositional components. In this sense, the photographic project was fundamental. It included a phase of definition of the themes and of inspections carried out in the different seasons that led to the realization of photos. These were then chosen to describe the landscape in its development in height. These studies resulted in thematic photomontages able to synthesize the local agricultural landscape. Meanwhile, a bibliographic research was carried out to identify the geomorphological and climatic characteristics of the area and the plant species present.

\section{Socio-cultural analysis}

Finally, the role of this cultural landscape in people's life was analyzed using interviews. The choice of interviews (Corbetta 1999) as a way of understanding is motivated by the aim of extrapolating the distinctive elements of the landscape. Moreover, each society has a different type of spatial organization and a distinct dialogue with the nature within which it is located (Turri 1974). In order to reach a holistic description, it is therefore necessary to explicit all aspects composing it, capturing the dynamism of everchanging scenarios, both chronologically and concerning testimonies, through the existing variety of points of views. So much so that, as mentioned above, the European Convention itself defines the landscape as: area perceived by people (Coe 2000). In the narration, the landscape takes on a historical dimension. The final representation obtained implies the impossibility of a definitive understanding, but it takes on depth. It is possible to read both the physical characteristics of the territory and the multiple signs that make it harmonious in the eyes of the interviewees. The landscape becomes alive, uniting the memory of individuals with the historical memory of the community. The survey was conducted using the semi-structured open-ended question interview instrument on 13 samples recorded in situ.

Once faithfully transcribed, the interviews were analyzed in order to isolate those recurring elements, recalled by a considerable number of people, identifiable as iconemes (Turri $1974,1979,2004$ ) or signs that make up the landscape. More specifically, a table was compiled for each interview to report landscape elements and dynamics recurring in the discourse. Terms were numbered and the textual citation, univocal name, and frequency were reported. An overall table was compiled once the interviews and analysis of individual interviews were completed. Here the terms previously noted, the number of interviews in which they were mentioned, the calculation of the frequency of the terms in all interviews, and the total number of mentions made by the totality of the interviewees were reported (de Pasquale 2018). The elements that are referred to by eighty percent of the cases studied are classified as iconemes (Lynch 1960, 1976; Turri 1979; Corbetta 1999). 


\section{Results}

The results show that the area under consideration is a traditional rural landscape, and specifically that the percentage of non-historic surface within the site is acceptable. In fact, applying the parameters given by the National Rural Landscape Observatory (Agnoletti and Tempesta 2016), SPT: superfice totale di territorio candidate (the total area of candidate territory), SPRS: superficie di paesaggio rurale storico (the area of historical rural landscape), SPRNS: superficie di paesaggio rurale non storico (area of non-historical rural landscape), SPU: superficie di paesaggio urbano (the area of urban landscape) and the maximum percentage of the proposed area consisting of territory not occupied by the landscape of historic interest (Pmax) heve been defined. PRS is 1032.2 ha, 66\%; SPRNS is 420.2 ha, 27\%. SPU equals the sum of 32.6 ha, unchanged urban, with 79.3 ha, urbanization, equal to 111.9 ha, $7 \%$. The sum of the calculated areas is equal to SPT.

$$
\begin{gathered}
\mathrm{SPRS}+\mathrm{SPRNS}+\mathrm{SPU}=\mathrm{SPT}=1564.4 \mathrm{ha} \\
\mathrm{P}_{\max }=100-190 / \mathrm{AT}^{0.192}=53.72 \%
\end{gathered}
$$

In the case of the candidate area:

$$
\text { SPRNS }(27 \%)+\text { urbanization }(5 \%)=32 \% \text {. }
$$

Therefore, since $32 \%<53 \%$ the portion of land without historical characteristics within the candidate area is confirmed to be lower than the threshold established by Pmax for the area itself.

Furthermore, it has been proved that the landscape under consideration is a cultural landscape, in which people recognize themselves, and with an important role in the local community's quality of life, as reflected in the words of one of the interviewees.

As a result for the Historical and Cultural Evaluation approach, for 1954 (Figs. 8, 9), six land uses were detected: arable land and meadows, vegetable gardens and orchards, vineyards, urban and anthropized areas, forests, shrub and arboreal vegetation. In the agricultural field, the first macrocategory includes all the traditional crops often practiced in rotation: buckwheat, barley, rye, corn, potatoes, hay and meadows. The second category combines vegetable gardens and orchards, plots often adjacent to houses and very small, in fact, these patches do not reach large surfaces. The last agricultural land use concerns vineyards, a very minor cultivation at these altitudes and which enjoys a privileged economy if compared to other local practices. In forestry, the lack of sharpness of the 1954 orthophotos did not allow to distinguish shrub areas, often rocky and to date clearly recognizable, from arboreal areas, areas with the presence of trees of reduced size and less dense distribution than wooded areas. As of 2015 (Figs. 10, 11), eight land uses have been identified, the six already present in ' 54 with the distinction between arboreal vegetation and shrublands and with the introduction of a last category, that of fallow land, previously absent in the territory.

While an accurate division of the land patches according to land uses was possible for the present day, the quality of the 1954 aerial photo did not allow for a clear identification of all the agricultural land patches, causing inaccuracy in the study of the evolution of land parceling.

The identification of the evolutionary dynamics and the quantification of the portions of the territory, unchanged and subject to change, was done through cross tabulation (Fig. 12). The result of the analysis is a transition matrix, a table which shows in the 


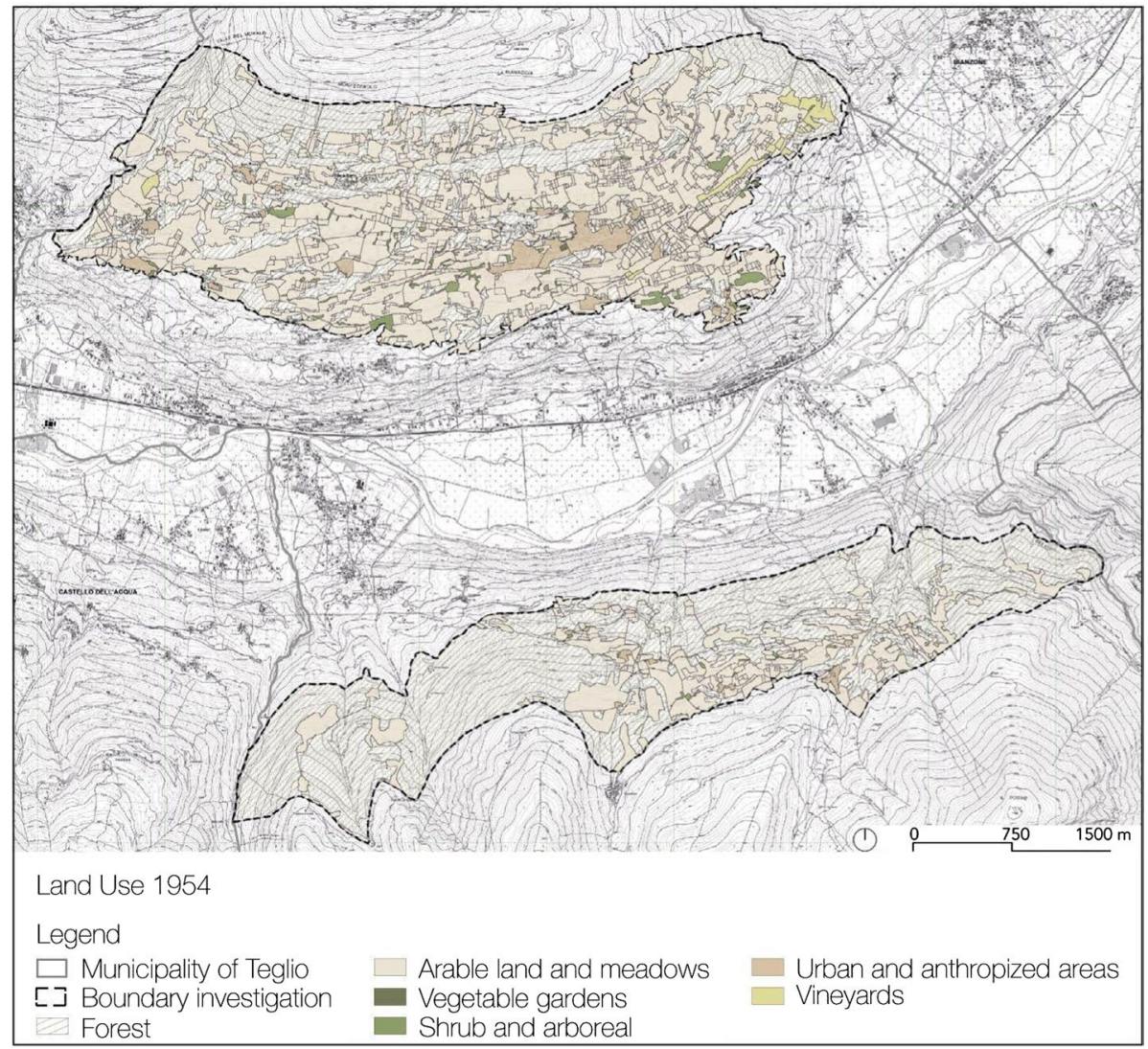

Fig. 8 VASA Methodology. Land use 1954

\begin{tabular}{ccc}
\hline Land $\cup$ se 1954 & Surface ha & Surface \% \\
\hline urban and anthropized areas & 36 & 2 \\
\hline gardens and orchards & 0 & 0 \\
\hline arable land and meadows & 679 & 43 \\
\hline vineyards & 11 & 1 \\
\hline forest & 818 & 1 \\
\hline shrub and arboreal vegetation & 20 & 100 \\
\hline
\end{tabular}

Fig. 9 VASA Methodology. Table land use 1954 


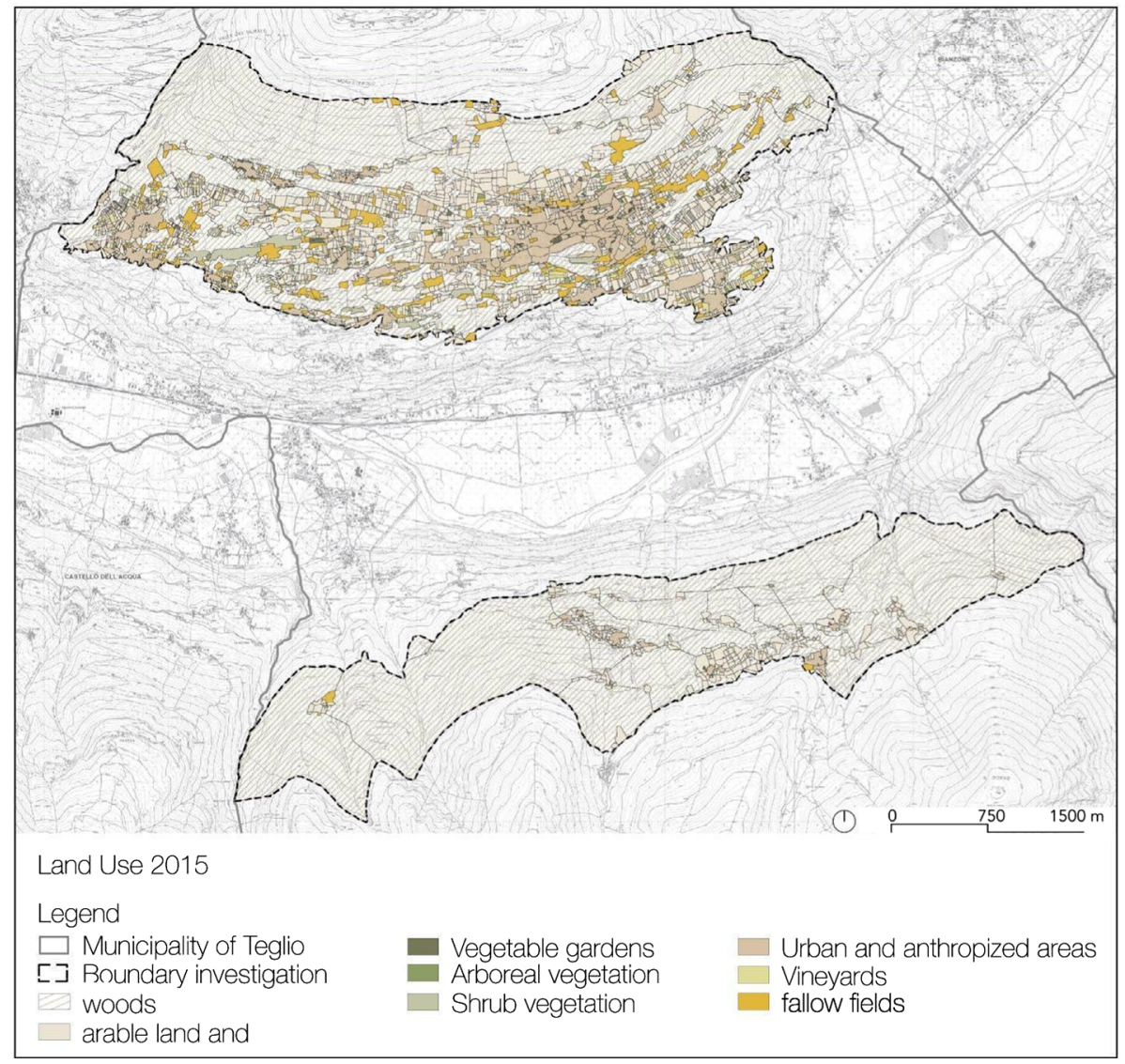

Fig. 10 VASA Methodology. Land use 2015

last row and in the last column the total quantities, in terms of hectares, of the various land uses, in terms of hectares, of the various land uses (Agnoletti and Tempesta 2016) respectively surveyed as of 1954 and as of 2015. Each row contains the transformation and permanence data of a specific land use, each column allows to visualize the quantity that, of each specific land use detected in 1954, has moved or remained in the various land uses as of 2015. To facilitate summary reading through the classes of permanence and transformation, each cell of the matrix has been highlighted with a color corresponding to one of the seven dynamics of transformation.

The final result (Figs. 13, 14) indicates that, in the study area, there is a persistence of land uses of $68.1 \%$. Between 1954 and 2015, there was a large increase in forested area -from 52 to $69 \%$ of the area-, a sharp decrease in arable and grassland -from 43 to $18 \%$-, and a slight expansion of urban agglomerations, from 2 to $7 \%$. Other land uses have not undergone significant quantitative changes. The most widespread phenomenon in the Municipality is forestation, which has occurred in $20.5 \%$ of the area under analysis, while deforestation, often practiced to obtain space for new buildings, has affected a very small portion of the territory, $2.5 \%$, compared to an anthropization of $5.1 \%$. 


\begin{tabular}{ccc}
\hline Land Use 2015 & Surface ha & Surface \% \\
\hline urban and anthropized areas & 112 & 7 \\
\hline gardens and orchards & 8 & 18 \\
\hline arable land and meadows & 282 & 1 \\
\hline vineyards & 12 & 69 \\
\hline forest & 1078 & 0 \\
\hline shrub vegetation & 3 & 1 \\
\hline fallow fields & 16 & 100 \\
\hline Total & 54 & 1564 \\
\hline
\end{tabular}

Fig. 11 VASA Methodology. Table land use 2015

\begin{tabular}{|c|c|c|c|c|c|c|c|c|c|c|}
\hline & \multicolumn{9}{|c|}{ Land use 2015} \\
\hline & & \begin{tabular}{|c|} 
urban and \\
anthropized \\
areas
\end{tabular} & forest & $\begin{array}{l}\text { fallow } \\
\text { fields }\end{array}$ & \begin{tabular}{|c|} 
gardens and \\
orchards
\end{tabular} & $\begin{array}{l}\begin{array}{c}\text { arable land } \\
\text { and } \\
\text { meadows }\end{array} \\
\end{array}$ & $\begin{array}{c}\text { arboreal } \\
\text { vegetation }\end{array}$ & $\begin{array}{c}\text { shrub } \\
\text { vegetation }\end{array}$ & vineyards & Total \\
\hline \multirow{7}{*}{ 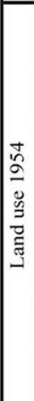 } & \begin{tabular}{|l} 
urban and \\
anthropized areas
\end{tabular} & 32,7 & 0,4 & 0,2 & 0,9 & 1,4 & 0,0 & & 0,2 & 35,8 \\
\hline & forest & 19,2 & 764,6 & 4,5 & 1,6 & 25,7 & 0,2 & 1,5 & 0,5 & 817,8 \\
\hline & $\begin{array}{l}\text { gardens and } \\
\text { orchards }\end{array}$ & 0,0 & & 0,0 & 0,2 & & & & & 0,2 \\
\hline & $\begin{array}{l}\text { arable land and } \\
\text { meadows }\end{array}$ & 56,5 & 294,1 & 46,9 & 5,0 & 249,1 & 2,6 & 14,8 & 10,2 & 679,3 \\
\hline & $\begin{array}{l}\text { shrub and arborea } \\
\text { vegetation }\end{array}$ & 3,5 & 9,8 & 1,2 & 0,0 & 4,9 & 0,3 & 0,1 & 0.2 & 20,0 \\
\hline & vineyards & 0,1 & 9,0 & 0,8 & & 0,7 & & & 0,7 & 11,3 \\
\hline & Total & 112,0 & 1077,8 & 53,6 & 7,7 & 281,8 & 3,1 & 16,5 & 11,9 & 1564,4 \\
\hline
\end{tabular}

$\square$ Stable
Intensification
Built up
Forestation
Extensification
Deforestation

Fig. 12 Cross tabulation

Although studies do not show the presence of uncultivated land in 1954, but only in 2015, extensification is small, 3.2\% of the area, and concerns both abandoned land and land where a return to traditional land uses has taken place, where urban areas have been 


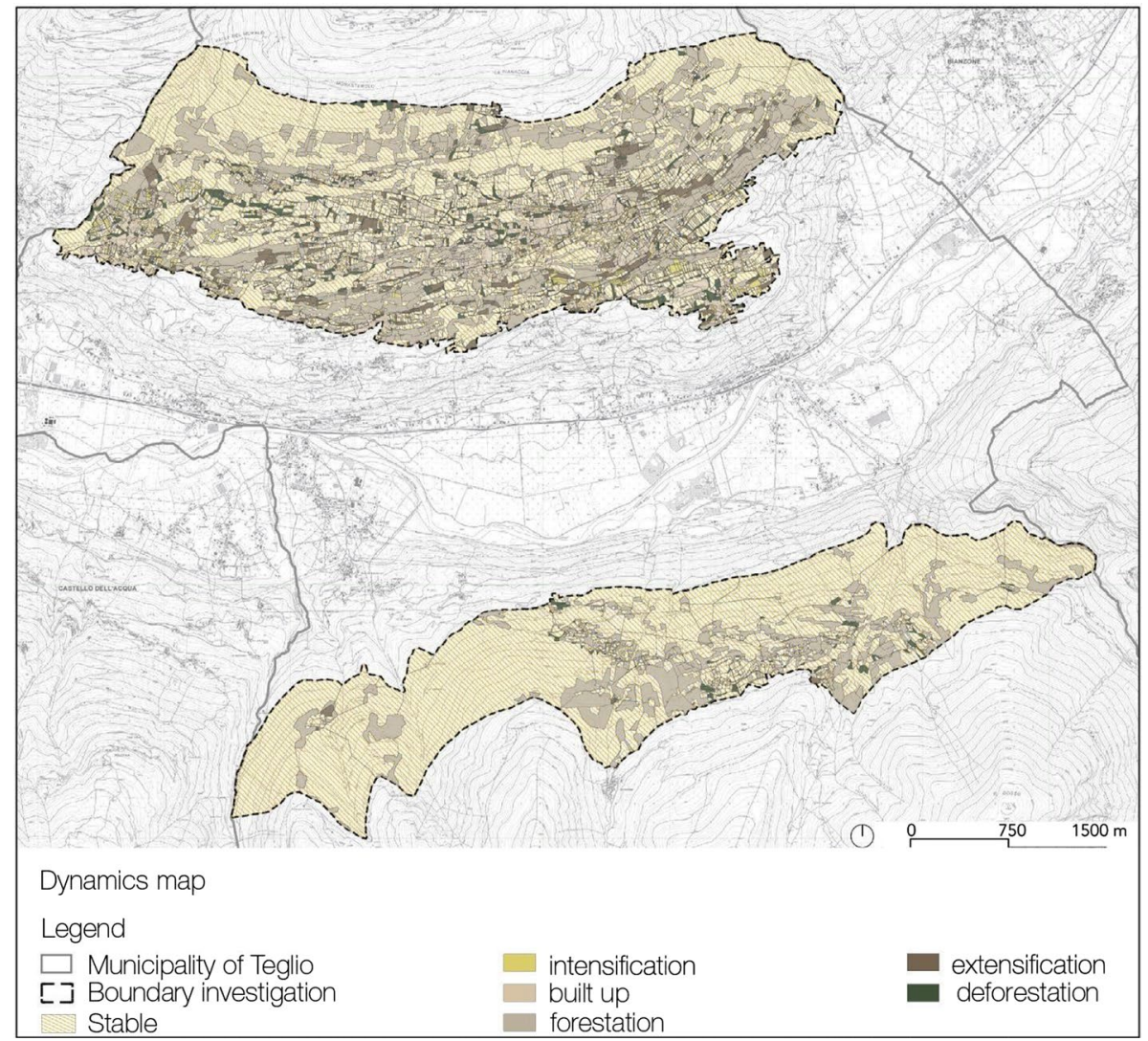

Fig. 13 VASA Methodology. Dynamic's map

converted to vegetable gardens and orchards or arable land and meadows or vineyards. Intensification has manifested itself in the increase in the cultivation of vines to the disadvantage of arable land and meadows, but it is an almost absent phenomenon, $0.7 \%$.

With regard to socio-economic aspects, in the study area there is a constant phenomenon of population decrease (- $0.2 \%$ from 2011 to 2018, $-0.3 \%$ from 2001 to 2011), accompanied by an increase in senilization, evidenced by the old age index, almost doubled compared to 1991 and by the incidence of the resident population aged 75 and over, 8.9 in 1991, 13.6 in 2011. Population tends to settle in isolated residences rather than in the nuclei, so much so that old buildings in historical city centers are often abandoned in favour of modern structures, contributing to a consequent decrease in population density (44.4 inhabitants $/ \mathrm{km}^{2}$ in 1991, 41.6 inhabitants $/ \mathrm{km}^{2}$ in $2001,40.4$ inhabitants $/ \mathrm{km}^{2}$ in 2010). As of 2011 , out of $57.7 \%$ of the employed, only $7.1 \%$ were actually employed in agriculture, with the lowest percentage when compared to other occupational areas. The most employed sector in 2011 is the tertiary sector, with $40.2 \%$.

If the data relating to the Total Agricultural Area (68\%) highlights the rural vocation, the data relating to the Utilized Agricultural Area (37\%) confirms the phenomenon of abandonment of the territory: 63\% of the Total Agricultural Area remains unused. The comparison between the 5th and 6th Census of Agriculture shows a reduction in the 


\begin{tabular}{ccc}
\hline Dynamics & Surface ha & Surface \% \\
\hline built up & 79,3 & 5,07 \\
\hline deforestation & 38,7 & 2,47 \\
\hline extensification & 50,4 & 3,22 \\
\hline forestation & 320,9 & 20,51 \\
\hline intensification & 10,2 & 0,65 \\
\hline stable & 1064,9 & 68,07 \\
\hline Total & 1564,4 & 100,00 \\
\hline
\end{tabular}

Fig. 14 VASA Methodology. Dynamisc map table

number of farms of 34\%. There are 297 farms registered in Teglio, $45 \%$ of the farms are individual, while a previously absent legal form is noted, that of the institution or municipality that manages collective property. Agriculture is now an income integration activity, conducted by family management (64\% of workers) with a mostly male presence (66\%). As far as age is concerned, only $16 \%$ of the workforce is between 19 and 39 years old, while $43 \%$ is between 40 and 59 years old and the remaining $41 \%$ is over 60 years old (Istat 2011). The only companies present are of medium or small size, especially on the slopes. Among the others, to take care of the territory, the Slow Food Presidium on Saracen Wheat has attempted a reorganization of the production process to safeguard the crops.

All the farms in the municipality of Teglio are dedicated to crop production and $32 \%$ of companies also carry out breeding activities. Data on specific cultivations of the territory are lacking especially in reference to specific municipal crops and in particular buckwheat.

The data available to the Municipality report that in the year 2017-2018 were declared 11.90 hectares cultivated with buckwheat compared to 5.13 hectares declared in 2006-2007 consequently we can see an increase of $43 \%$ of crops. Also this data is not certain as there is no obligation to declare the cultivations. In any case this last data is very positive, in fact, although it is evident a progressive diminishing of the use in agriculture, the cultivation of typical cereals is witnessing a slow recovery.

Tourism is enogastronomical, naturalistic and sports, linked to cycling and second homes. The rate of tourism is medium to high, 1001-10,000 presences every 1000 inhabitants (Ancona and Fossi 2016).

The analysis of the social perception of the landscape by the local community has shown that the population maintains a very close link with the land and that there is a strong relationship between traditions and land uses.

The overall table (Fig. 15) shows in red the landscape elements mentioned most often by the total number of interviewees. The highlighted iconemes in particular are: woods, fields, vineyards, buckwheat, chestnuts, rye, meadows, seed, abandonment. 


\begin{tabular}{|c|c|c|c|c|}
\hline N. & Iconemi & $\begin{array}{c}\mathrm{n} . \\
\text { interviews }\end{array}$ & Interviews and citation frequency & Total \\
\hline 1 & wood & 12 & 4x(N1N7N12N13), 3x(N2N3N5N9), 2xN4, 9xN6, 8xN10, 1xN11, & 48 \\
\hline 2 & fields & 13 & 8xN1, 4x(N2N8N12), 14xN3, 5x(N4N9N11), 2x(N5N6N7), 3x(N10n13) & 61 \\
\hline 3 & plant & 8 & 5xN1, 1x(N2N10N11), 4xN3, 5xN6, 2x(N9N12) & 21 \\
\hline 4 & trees & 6 & 2x(N1N2N7), 4x(N3N10), 1 xN11 & 15 \\
\hline 5 & vineyards & 10 & 1xN1, 3xN4, 2x(N5N6N8N9N11), 7xN7, 4xN10, 5xN13 & 30 \\
\hline 6 & buckwheat & 12 & 9x(N1N4N12), 6x(N2N3N11), 14xN5, 1x(N6N7N10), 10xN8, 12xN13 & 85 \\
\hline 7 & dry stone walls, murache & 9 & 2x(N1N2), 1x(N4N7N8N10N12), 3xN5, 7xN13 & 19 \\
\hline 8 & mountain & 9 & 3x(N1N5N7N8), 2x(N2N3), 4xN4, 7xN9, 1xN11 & 28 \\
\hline 9 & chestnuts & 10 & 7xN1, 10xN2, 3xN3, 2x(N4N11), 1x(N5N6N12), 5x(N8N10) & 37 \\
\hline 10 & ne & 10 & 16xN1, 4x(N2N13), 3x(N3N4N6N8), 2xN5, 1xN11, 10xN12 & 49 \\
\hline 11 & mill & 6 & $1 \times(N 1 N 5 N 13), 2 \times N 2,4 \times N 3,5 \times N 4$ & 14 \\
\hline 12 & potatoes & 7 & 7xN1, 4xN2, 3x(N4N11), 6x(N8N12), 1xN10, & 30 \\
\hline 13 & bees, beekeeping & 3 & $6 \times N 1,1 \times N 3,4 \times N 5$ & 10 \\
\hline 14 & meadows & 13 & 2x(N1N4N6), 5x(N2N7N11),3x(N3N9N12N13), 1x(N5N8), 9xN10 & 44 \\
\hline 15 & cow & 6 & $1 \times N 1 N 7,8 \times N 2,4 \times N 3,3 \times N 5,34 \times N 9$ & 51 \\
\hline 16 & hay & 5 & 1x(N1N8N11), 5xN2, 3xN3, 7xN9 & 17 \\
\hline 17 & bam & 3 & $1 \times N 1,3 \times(\mathrm{N} 2 \mathrm{~N} 9)$ & 7 \\
\hline 18 & dumega & 2 & $2 \times N 1,3 \times N 8$ & 5 \\
\hline 19 & barley & 6 & 2xN1, 1x(N2N4N5), 3xN8, 1xN12 & 9 \\
\hline 20 & seed & 10 & 2x(N1N9N13), 1x(N2N5N10N11), 8xN4, 10xN8, 7xN12 & 33 \\
\hline 21 & fallow & 4 & $4 \times(N 6 N 7), 2 \times N 10,3 \times N 13$ & 13 \\
\hline 22 & abandonment & 12 & $3 \times(N 1 N 8), 2 \times(N 2 N 11 N 6), 1 \times(N$ 3N 4N $7 N$ 9N 10N 12), 4XN 5 & 23 \\
\hline 21 & farming & 5 & $2 \times N 2 N 13,1 \times N 3,4 \times N 4,3 \times N 9$ & 12 \\
\hline 22 & alpine pasture & 7 & 2xN3, 6xN4, 5xN5, 3x(N6N9), 1x(N10N12) & 21 \\
\hline 23 & paths & 6 & 3x(N2N9), 2x(N5N13), 1x(N7N8) & 12 \\
\hline 24 & terrace & 6 & 1x(N3N4N8N12), 2x(N7N11) & 8 \\
\hline 25 & chestnut wood & 4 & $2 \times N 4,1 \times N 5,5 \times N 7,3 \times N 8$ & 11 \\
\hline 26 & grazing & 8 & 1x(N2N10N12), 5xN4, 3xN5, 4xN6, 2x(N9N13) & 18 \\
\hline 27 & fir & 5 & 3xN4, 1xN6, 6xN10, 1x(N11N12) & 12 \\
\hline 28 & larch & 5 & 2xN4N6, 10xN10, 1xN11, 1xN12 & 14 \\
\hline
\end{tabular}

Fig. 15 Table of iconemes. First column: number. Second column: iconemes. Third column: number of interviews in which the iconeme was cited. Fourth column: calculation of the number of total mentions of the iconeme in the total interviews (frequency of the quote multiplied by the number of interviews with the same frequency). Fifth column: total number of citations

Therefore, the landscape is described by the inhabitants through the various crops that make it up of buckwheat, rye, hay, potatoes, vegetable gardens, chestnuts and wine, and that are developed on certain elevations. In the landscape the signs of noble owners, farmers and nature are combined. Often, a general narrative linked to seasons and tones, is followed by the recollection of the vegetation of particular areas, that during the interviewees' childhood was present and that over the years has been lacking. In each interview there is a recurring reference to the poverty of the people who were once driven to shape the land for their livelihood. Each family owned or tended to small plots of land scattered throughout the territory. Vegetable patches, along with chicken coops, the ciun, pig pens and pastures were in close proximity to the house. Each family had on average two to three cows/livestock and lived a nomadic life that required moving from the bottom of the valley to the 
maggengo, from the maggengo to the mountain pastures, and then returning to the middle of the slope to start the cycle again. This entailed the territory was lived holistically, as life had a slow pace and roads were clean, not because of maintenance but for usage.

"Now here in the spring there are all the flowers, all the wild cherry trees, even in May, then in May in the meadows there are all the yellow flowers, the dogtooths violet. In the middle of June the meadows start to get ripe and it gets nice and blond even for the rye. And then there are the patches of golden color depending on what gets mowed and what doesn't. In July it gets all green and the buckwheat is planted and starts to grow. The month of September is the most beautiful with all the fields blooming, all white. All the plants in bloom and the buckwheat fields white."

Along with sentiments of pride for the work of their ancestors, nostalgic feelings for a past that no longer exists are evoked and emerge in the interviews: today, familial agricultural activity has progressively been abandoned or has transitioned into a second job. Initially it was actively carried out, but with the passing of the generations, it transformed into a pastime. Cooperation within neighbourhoods is reduced to mutual aid in occasional agricultural work, but there is still competition between villages and between the mountainsides that hinders collective communication aimed at protecting the territory. The loss of identity is the main critical issue. Although a strong bond with the territory survives, there is no setting that allows traditions to remain alive and evolve. The absence of a united community is one of the greatest impediments to the possibility of creating an estate that encourages agricultural regeneration.

\section{Discussion}

Integrating socio-cultural research with historical-environmental analysis, we can distinguish between practices that still exist and those that have been lost. The expansion of cultivation, the self-sufficiency of families, the integrated use of the resources of the two sides, the division of goods between collective, community and private and the distinction between tense and free forests are no longer practiced. The cultivation of walnuts has disappeared. The forest has lost its distinctly productive character and the internal road system has often been erased by naturalization. Swine breeding is considerably reduced and sanitary regulations have led to a clear division between spaces dedicated to livestock and to man. Cattle breeding has been considerably reduced and the Bruno Alpina breed is now flanked by the Friesian breed. On the other hand, the cultivation of arable land and meadows, vegetable gardens, orchards and chestnut groves persists and agricultural practices are still carried out mainly according to traditional techniques.

Therefore, in the area under examination the phenomenon of crop abandonment and naturalization persists. The same phenomena can be found throughout the Italian inner areas (ONPR 2018) and in particular in the alpine rural landscapes already registered in the Register of Historic Rural Landscapes, in which unused and reforested cultivated fields are reported among the terraces (della Vedova 2020; Neonato 2020).

Starting from the analysis carried out, a strategy was proposed that consists of multiple actions to be activated during a multi-year pathway. For the drafting of the latter, successful projects active on the Italian territory were taken as a model and in particular the Alta Valtellina Strategy (Comunità Montana Alta Valtellina 2021; Canobio et al. 2020), within SNAI, and AttivAree (Fondazione Cariplo 2021), promoted by Fondazione Cariplo. The 
stakeholders identified are mainly public and private institutions that have the possibility of action and interest in the rural landscape of Teglio and in the cultural development of the municipality. To these must be added companies, individual producers, processors, then mills, vendors and citizens.

This strategy aims to complement the initiatives already in place and to systematize different interventions into a broad overview. Among the active projects, Coltivare Valore for the recovery of uncultivated land, the cultivation of medicinal herbs and social inclusion and ConserVa for the identification of local varieties of rye and buckwheat is being carried out, the results of which are about to be published; meanwhile recent research on Siberian wheat has already demonstrated the adaptive capacity of the species on Valtellina soil to be implemented for innovative production of nutraceutical products (Borgonovo et al 2019).

The groups of actions shown in Fig. 16 in which the name of the group, the individual actions that compose it and the funds dedicated to the theme are indicated. In particular, it focuses on strengthening the community by creating moments and places to meet and encouraging the formation of an awareness of the territory and its specificity in the new generations. Having identified strong rural characteristics in the area, we focus on agriculture for the regeneration of the area and propose actions such as the creation of a brand

\begin{tabular}{|c|c|c|}
\hline Action group & Action & Funds \\
\hline \multirow{3}{*}{$\begin{array}{l}\text { Strengthening the community and } \\
\text { integration among local, regional, national, and } \\
\text { supranational entities. }\end{array}$} & Tellino Space, a multifunctional center in the main towr & \multirow{3}{*}{$\begin{array}{l}\text { European structural and } \\
\text { investment funds (ESIF) } \\
\text { Axis IV; European } \\
\text { Regional Development } \\
\text { Fund (ERDF) Axis I }\end{array}$} \\
\hline & Development Visions, meetings to promote the territory & \\
\hline & Tellino Laboratory, a space for young people & \\
\hline \multirow{2}{*}{$\begin{array}{l}\text { Strengthening the integration between school and } \\
\text { territory }\end{array}$} & On-site education. & \multirow{2}{*}{$\begin{array}{l}\text { European structural and } \\
\text { investment funds } \\
\text { (ESIF)Axis III }\end{array}$} \\
\hline & School-to-Work Alternation. & \\
\hline \multirow{7}{*}{$\begin{array}{l}\text { Recovery of traditional agricultural activities, } \\
\text { maintenance of land management activities. }\end{array}$} & Ecosystem Incentives & \multirow{7}{*}{$\begin{array}{c}\text { Rural Development } \\
\text { Program Lombardy Region } \\
\text { measures } 3.1 .01 ; 3.2 .01 ; \\
\text { 4.3.01; } 7.6 .01 ; 8.6 .02 ; 10 ; \\
11.1 .01 ; \\
\text { 11.1.02; } 16.9 .01 ; 16.10 .01\end{array}$} \\
\hline & Teglio's Seeds Chain & \\
\hline & Brand "Historic rural landscape" & \\
\hline & Land Association & \\
\hline & Promotion of biological products & \\
\hline & Promotion of horticulture, fruit farming, beekeeping & \\
\hline & Recovery silvo-pastoral activities. & \\
\hline \multirow[t]{2}{*}{$\begin{array}{l}\text { Strengthening and development of } \\
\text { research projects }\end{array}$} & Genetic analysis and preservation of local species & \multirow{2}{*}{$\begin{array}{c}\text { Rural Development } \\
\text { Program Lombardy Region } \\
\text { measures } 10.2 .01 ; \\
\text { European Regional } \\
\text { Development Fund (ERDF) } \\
\text { Axis I }\end{array}$} \\
\hline & Ad hoc mechanization for mountainous areas. & \\
\hline Urban regeneration & Mapping and restoration plan for abandoned places & urban planning \\
\hline \multirow[t]{5}{*}{$\begin{array}{l}\text { Increase in presences related } \\
\text { to outdoor activities and the rural landscape }\end{array}$} & $\begin{array}{l}\text { Training for tourism and cultural enhancement of the } \\
\text { rural landscapt }\end{array}$ & \multirow{5}{*}{$\begin{array}{c}\text { European Regional } \\
\text { Development Fund (ERDF) } \\
\text { Axis III }\end{array}$} \\
\hline & Rural bicycle and pedestrian itineraries & \\
\hline & Enhancement of the Dos de la Forca Archaeological Par & \\
\hline & From self-consumption to agritourism & \\
\hline & Widespread hotel in Teglio. & \\
\hline
\end{tabular}

Fig. 16 Table illustrating the proposed development strategy for the area 
linked to the landscape, the birth of a short supply chain, the payment of ecosystem services, the land association and the recovery of abandoned practices. To this end, the need for collaboration with research centers and universities is identified for the characterization of the species present and for ad hoc technological integration. The suggested interventions include an action on the built landscape that involves a recovery plan of rural buildings. Finally, for an active regeneration and to implement agricultural multifunctionality, ecotourism is identified as a solid possibility of income integration.

\section{Conclusions}

The study of history, land and community, is an important element of understanding biocultural diversity. By crossing anthropological elements with biological data, it is possible to reconstruct a complete vision of the landscape, involving objective data and genius loci (Christian Norberg-Schulz 1979). The rebalancing of the social, economic and environmental components in the mountains or in the inner areas is useful to solve the critical issues highlighted by the study, especially to contrast the abandonment of the rural areas and the increase of the spontaneous forest.

In this sense, to maintain the high value of biocultural diversity is not only important to maintain the traditional production systems, but rather at achieving continuity with the cultivation traditions, restoring the self-sustainability and multidimensionality of agriculture. Retro-innovation (Banks et al. 2000), the innovative reintroduction of peasant modes of production that participate in local ecological complexity and are socially and economically recognized (Magnaghi 2012) is the real aim. The challenge is part of a broader discourse of integration of mountain areas, whose importance is recognized, for water supply and hydroelectricity, for environmental protection and from hydrogeological hazards (SdT 2019), for the community and associational culture to be recovered. Eco-tourism is identified as an economically driving sector of peasant agriculture (Cavazzani 2008). In fact, multifunctionality allows the peasant model to pursue economic development outside of the market logics that have caused its impoverishment (van der Ploeg 2008). Recognition of the quality of the product and coupling it with other rural activities could be the first step towards making agricultural work sustainable again.

The regeneration of mountain territories participates in the mending of reciprocal relationships between urban and marginal systems, builders of identity, to achieve new social, economic and environmental balances (Magnaghi 2012).

As a living heritage (UNESCO 2019), the objective for the maintenance of its values is an active safeguard (Coe 2005) aimed at involving and empowering the local community, extending the community of inheritance (Coe 2005) and activating growth processes. In this context, the role of traditional agriculture is fundamental, as an element of community cohesion and as a guarantor of the maintenance of cultural biodiversity, which today is in danger throughout the Mediterranean area.

Acknowledgements We would like to express our acknowledgement to: the Associazione Per La Coltura Del Grano Saraceno Di Teglio E Dei Cereali Alpini Tradizionali for their collaboration and support for the research activities on site; the Department of Agricultural, Food, Environmental and Forestry Sciences and Technologies (DAGRI), University of Florence for support in drafting the VASA (Historical Environmental Assessment) analysis carried out in a GIS environment; the Office of Private Construction (SUED) and Urban Planning of the Municipality of Teglio for technical support. 
Funding Open access funding provided by Università degli Studi Roma Tre within the CRUI-CARE Agreement. This research has been developed within the Department of Architecture of the University Roma Tre as part of Eugenia Spinelli's master thesis.

Data availability Data will be provided by the authors upon request.

\section{Declarations}

Conflict of interest The authors declare no conflict of interest.

Consent to participate Not applicable.

Consent for publication Not applicable.

Ethical approval Not applicable.

Open Access This article is licensed under a Creative Commons Attribution 4.0 International License, which permits use, sharing, adaptation, distribution and reproduction in any medium or format, as long as you give appropriate credit to the original author(s) and the source, provide a link to the Creative Commons licence, and indicate if changes were made. The images or other third party material in this article are included in the article's Creative Commons licence, unless indicated otherwise in a credit line to the material. If material is not included in the article's Creative Commons licence and your intended use is not permitted by statutory regulation or exceeds the permitted use, you will need to obtain permission directly from the copyright holder. To view a copy of this licence, visit http://creativecommons.org/licenses/by/4.0/.

\section{References}

Agnoletti M (2006a) The Conservation of Cultural Landscapes. CABI, Cambridge. https://doi.org/10.1079/ 9781845930745.A

Agnoletti M (2006) Documento per il Piano Strategico Nazionale - Paesaggio. Contributo tematico alla stesura del Piano Strategico Nazionale. https://www.reterurale.it/flex/cm/pages/ServeBLOB.php/L/IT/ IDPagina/1624

Agnoletti M (2007) The degradation of traditional landscape in a mountain area of Tuscany during the 19th and 20th centuries: Implications for biodiversity and sustainable management. For Ecol Manage 249:5-17. https://doi.org/10.1016/j.foreco.2007.05.032

Agnoletti M (2010) Paesaggi rurali storici, per un catalogo nazionale. LaTerza editore. Bari

Agnoletti M (2013) Italian historical rural landscapes. Cultural values for the environment and rural development. Springer

Agnoletti M (2014) Rural landscape, nature conservation and culture: Some notes on research trends and management approaches from a (southern) European perspective. Landsc Urban Plann 126:66-73

Agnoletti M, Rotherham ID (2015) Landscape and biocultural diversity. Biodivers Conserv 24:3155-3165

Agnoletti M, Tempesta T (2016) Linee guida per il dossier di candidatura all'osservatorio nazionale del paesaggio rurale. ISMEA. https://www.reterurale.it/flex/cm/pages/ServeBLOB.php/L/IT/IDPagina/ 13826. Accessed 15 March 2021

Ancona F, Fossi L (2016) Dossier statistico. Osservatorio regionale del turismo e dell'attrattività. Il turismo in Lombardia. Europolis Lombardia. Milano

Bacchetta G, Ercole S, Fenu G, Genovesi P, Giacanelli V, et al (2016) Manuali per il monitoraggio di specie e habitat di interesse comunitario (Direttiva 92/43/CEE) in Italia: specie vegetali. ISPRA. Serie Manuali e linee guida. 140/2016.

Banks J, Bristow G, Marsden T (2000) Food supply chain approaches: exploring their role in rural development. Sociologia Ruralis

Barbera G (2019). Antropocene, Agricoltura e Paesaggio. Considerazioni a margine di un viaggio in Cina. Aboca S.p.A. Società Agricola. Sansepolcro

Barbera G (2021). Il giardino del Mediterraneo. Il Saggiatore s.r.l. Milano

Barca F et al (2014) Strategia Nazionele per le Aree Interne: definizioni, obiettivi, strumenti e governance. Collana Materiali Uval, Roma 
Benedetti A, Benedetti D (1984) Valtellina e Valchiavenna. Dimore rurali. Jaca Book. Milano

Bonardi L, Caligari A, Foppoli D, Gadola L (2014) Paesaggi valtellinesi: Trasformazione del territorio, cultura e identità locale. Mimesis. Milano

Borgonovo G, Giupponi L, Panseri S et al (2019) Multidisciplinary study of a little known landrace of Fagopyrum tataricum Gaertn. of Valtellina (Italian Alps). Genet Resour Crop Evol 66:783-796. https:// doi.org/10.1007/s10722-019-00755-z

Berti L, Branchi E (2002) Dizionario tellino. IDEEV: Istituto di Dialettologia e di Etnografia Valtellinese e Valchiavennasca. Sondrio.

Braudel F (2003). Il Mediterraneo. Bompiani. Milano

Buzzetti I (2005) Castagneti da frutto, un patrimonio valtellinese da recuperare. Ente Regionale per i Servizi all'Agricoltura e alle Foreste (ERSAF), Lombardia

Canobio R, Dadone F, Nova M (2020) Monitoraggio ambientale integrato degli strumenti attuativi del POR e del PSR. PSL della Valtellina e Strategie delle Aree interne Alta Valtellina e Valchiavenna. Autorità Ambientale regionale. Lombardia

Cavazzini A (2008) Processi di resistenza in agricoltura e reti alternative. In: Paciola G, Giannotta P (2009) L'altra agricoltura. Verso un'economia rurale sostenibile e solidale. Agriconsulting. http://dspace.crea. gov.it/handle/inea/726

Cicardi MG (2005) Conoscere il paesaggio. La vegetazione: un percorso dal fondovalle agli alpeggi. Fondazione Luigi Bombardieri Sondrio. Sondrio

Coe (2000) Convenzione Europea del Paesaggio. Council of Europe https://www.coe.int/it/web/conve ntions/full-list/-/conventions/treaty/176. Accessed 13 May 2021

Coe (2005) Convenzione quadro del Consiglio d'Europa sul valore dell'eredità culturale per la società. Faro. https://www.coe.int/it/web/conventions/full-list/-/conventions/treaty/199. Accessed 16 May 2021

Comunità Montana Alta Valtellina (2021) Alta valtellina aree interne. http://areeinternealtavaltellina.it/. Accessed 13 Apr 2021

Corbetta P (1999) Metodologia e tecniche della ricerca sociale. Il Mulino, Bologna

Della Vedova T, et al. (2020) Vigneti Terrazzati del Versante Retico della Valtellina. https://www.reterurale. it/

de Pasquale G et al (2018) Paesaggio della Pietra a Secco dell'Isola di Pantelleria. pp 49-60. https://www. reterurale.it/

Emanueli F (2016) Il Paesaggio Rurale Storico E Tradizionale: Individuazione Degli Elementi Storici E Delle Fonti. ISMEA.

Ferranti R (2011) Il paesaggio vegetale nel territorio di Teglio. In Inventario dei toponimi valtellinesi e valchiavennaschi. Vol. 36. Società Storica Valtellinese. Villa di Tirano.

Ferranti R, Parolo G, Rossi G (2005) La flora di particolare interesse fitogeografico della provincia di Sondrio: un primo inventario per la sua conservazione. Biogeographia. https://doi.org/10.21426/B6261 10530

Fondazione Cariplo (2021) Attiv aree. http://attivaree.fondazionecariplo.it/. Accessed 14 May 2021

Giacomini V, Nangeroni G (1960) Ambiente fisico e paesaggio vegetale della Provincia di Sondrio. Camera di commercio, industria e agricoltura. Sondrio

Gianasso M (1971) L'ambiente naturale e umano della Provincia di Sondrio. Banca Popolare di Sondrio. Sondrio

Gironi F (2012) Aspetti generali della vegetazione. In: Palladini M (2012) VAS, Valutazione ambientale strategia, interna al PGT, Piano di Governo del Territorio. Comune di Teglio. Teglio

Guler Von Weineck G (1959) Raetia. Camera di commercio, industria e agricoltura. Sondrio.

Istat (2011) 8milaCensus una selezione di indicatori per ogni comune di Italia. http://ottomilacensus.istat.it/. Accessed 10 Apr 2021

Lynch K (1960) The image of the city. Mit Press, Cambridge

Lynch K (1976) Managing the sense of a region. Mit Press, Cambridge

Magnaghi A (2012) Politiche e progetti di territorio per il ripopolamento rurale. Quaderni del territorio. N. 2.

Merizzi G, Cicardi MG (2012) VAS, Valutazione Ambientale Strategica, Piano del Governo del Territorio. Comune di Teglio. Teglio.

Neonato F (2020) Il paesaggio rurale dei Vigneti terrazzati della Valle di Cembra. https://www.reterurale.it/

Norberg Schulz C (1979) Genius loci. Paesaggio ambiente architettura. Mondadori Electa. Milano

Osservatorio Nazionale dei Paesaggio Rurali, delle pratiche agricole e conoscenze tradizionali (2018) Primo rapporto sullo stato del paesaggio rurale. Università degli Studi di Firenze. https://www.reterurale.it/ flex/cm/pages/ServeBLOB.php/L/IT/IDPagina/18583

Osservatorio Regionale per la Biodiversità Lombardia (2021) Ricerca dati. http://ossnat.biodiversita.lomba rdia.it/. Accessed 15 May 2021 
Palladini M (2012) Piano di Governo del Territorio. Comune di Teglio. Teglio.

Van der Ploeg JD (2008) Percorsi di sviluppo rurale: il modello contadino. In: Paciola G, Giannotta P (2009) L'altra agricoltura. Verso un'economia rurale sostenibile e solidale. Agriconsulting. http://dspace.crea. gov.it/handle/inea/726

Rappelli F et al (2007) Definizione delle soglie pluviometriche d'innesco di frane superficiali e colate torrentizie: accorpamento per aree omogenee. IRER Istituto di Ricerca Regione Lombardia. Lombardia

Rivas-Martìnez S, Penas A, Díaz TE (2004) Bioclimatic map of Europe. Bioclimates. University of León. E-24071. Spain

Salsa A (2019) I Paesaggi Delle Alpi. Un viaggio nelle terre alte tra filosofia, natura e storia. Donzelli Editore. Roma

Sauer C (1925) The morphology of landscape. University of California Press, Berkeley

SdT (2019) Manifesto di Camaldoli per una nuova centralità della montagna. Società dei Territorialisti, SdT. http://www.societadeiterritorialisti.it/2020/04/12/manifesto-di-camaldoli-per-una-nuova-centr alita-della-montagna/. Accessed 14 May 2021

Sereni E (1961) Storia del Paesaggio agrario italiano. Laterza. Bari

Turri E (1974) Antropologia del paesaggio. Marsilio. Venezia

Turri E (1979) Semiologia del paesaggio italiano. Marsilio editori spa. Venezia

Turri E (2004) Il paesaggio e il silenzio. Marsilio editori. Venezia

Value Sustainable Agri-Food and Environment (2018) La riscoperta del grano saraceno. Criticità e opportunità per la filiera lombarda. Vsafe s.r.l. Università Cattolica del Sacro Cuore. Milano

UNESCO (2019) Living Heritage and Indigenous Peoples. United Nations Educational. Scientific and Cultural Organization (UNESCO). Paris. France. https://ich.unesco.org/doc/src/Brochure-indigenous-people-201904-EN.pdf. Accessed 14 May 2021

Zoia D (2004) La formazione dei caratteri storici del paesaggio valtellinese. Credito Valtellinese e Fondazione Luigi Bombardieri. Sondrio

Zoia D (1996) Teglio, terra dell'arcivescovo. Statuti e Ordini della Castellanza e del Comune di Teglio. Tipografia Poletti. Sondrio

Publisher's Note Springer Nature remains neutral with regard to jurisdictional claims in published maps and institutional affiliations. 